\title{
The Religious Perspective of Takaful as Ethical Insurance
}

Nawal Kasim

Associate Professor at Accounting Research Institute, Faculty of Accountancy, Universiti Teknologi MARA, Shah Alam, Malaysia

Sheila Nu Nu Htay

Professor at The Business School, Humber College, Toronto, Canada

Syed Ahmed Salman

PhD candidate and Research Assistant at Institute of Islamic Banking and Finance, International Islamic University Malaysia

Email:salmaniium@gmail.com

\author{
Doi:10.5901/mjss.2016.v7n4p
}

\section{Abstract}

Ethics is crucial in every part of human life irrespective of religion, race, place, and time. Every religion teaches its followers to be good and enjoin virtue. Ethical conduct is a mission central to any religion and ethical behaviour is highly demanded in any part of the world. As a result of the global financial crisis, regulators and related authorities are realising the importance of ethics as a defensive measure to avoid the recurrence of financial crises. Religions such as Islam, Christianity, Judaism Hinduism, Sikhism, and Buddhism condemn the practice and involvement in interest, gambling, and uncertainty as they are tools of injustice and create an atmosphere of inequality. Unfortunately, insurance involves the elements of interest, gambling, and uncertainty. Human beings seek an ethical and just business environment where they can finance, participate, and invest their capital without being involved in prohibited activities and elements. The objectives of this paper are to provide the reasons behind the prohibition of insurance not only from Islam but also from other religious perspectives and to show that the suitability of Takaful as an ethical insurance in all aspects of religious teachings. Takaful is a cooperative, mutual, and solidarity product that can be used as a risk management tool. The main advantage of Takaful over conventional insurance is that it is free from religiously forbidden elements and promotes a spirit of caring and sharing in the society. This knowledge should be disseminated to ensure that Takaful becomes the universal ethical insurance product.

Keywords: Insurance, Takaful, Religion and Ethics

\section{Introduction}

Ethics and religion are inseparable. Ethics is known as the guide to mould us to behave fairly and to create a harmonious society. Its role in cultivating civilised individuals and societies cannot be undermined. Due to its ability to regulate behaviour, ethics have interested researchers in the field of business. Many countries have issued ethical codes of conduct to guide business activities. In the contemporary corporate world, people are involved in interest, gambling, and uncertainty which are morally wrong. These practices corrupt the moral fibre of the society and leads to inequality thereby widening the gap between the rich and the poor. For instance, when interest is imposed on the borrower, the borrower needs to pay back the interest regardless of financial position and the lender is guaranteed a profit without assuming risk. In such a case, lending money does not help the borrower and constitutes an additional burden. This predicament favours the lender who is relatively more wealthy than the borrower. However, if the profit and loss sharing concept is used, this will be a non-issue. When the business is not doing well and incurs loss, it will be borne by the capital provider and the worker will lose his effort. When the profit is realised, both share in it. This offers a win-win situation to all the involved parties at any point of time.

Although some may not be directly involved in interest, gambling, and uncertainty, they might be indirectly involved through insurance. Insurance is used as a risk management tool to minimise or recover some of the financial loss that we might face. The concept of insurance is not against the Shari'ah but its activities are. Consequently, Takaful has been introduced as an alternative to insurance and as ethical insurance to promote fair and transparent products. Takaful is formulated based on Islamic ethics which are derived from the divine sources of the Quran and Sunnah. Takaful products are widely offered all over the world, including both Muslim and non-Muslim countries. It seems that it is getting 
acceptance by anyone regardless of religion. Thus, the objectives of this paper are to show why insurance is prohibited in Islam as well as in other religions and that Takaful is an ethical and alternative to insurance. This paper is prepared based on the documentary approach because this paper is theoretical or conceptual paper and it is more cost effective method than any other methods. The usage of documentary methods discourses the study of documents that encompass evidence about the existence we plan to study (Bailey 1994). Payne and Payne (2004) describe "the documentary method as the techniques used to categorize, investigate, interpret and identify the limitations of physical sources, most commonly written documents whether in the private or public domain". Library research method is used in additional to the documentary approach because adequate documents such as articles, books and internet sources are required to be referred in preparing this paper.

This paper is organised in five section. Section two discusses risk exposure and risk management in Islam. Section three elaborates on insurance according to Islam and other religions. Section four explains Takaful and its ethicality and the last section concludes the paper.

\section{Risk Exposure and Risk Management in Islam}

Risk is originated from the Arabic word "Risq" which is related to chance of outcomes and has neither positive nor negative implications. "Risk" is commonly used in English with a negative connotation (Alhabshi, Kamaruddin, Hamzah \& Ezamshah, 2012). Many researchers have provided definitions of risk, and the bottom line is that risk is an uncertain future condition which can create deviation from the desired outcome. Human beings are exposed to various types of risks. At the individual level, we are exposed to the risks of illness and accidents. The financial loss or expenses to remedy ailments or to pay for repairs in the case of accidents can expose us to huge financial risk that is not always affordable. Consequently, it becomes a financial burden. Business activities are exposed to different types of risks such as strategic risk, financial risk, operational risk, compliance (regulatory) risk, and other risks. Although the risks can provide opportunities to earn profit, risk exposure can also lead to losses. Thus, it is important to manage risks by both individuals and business entities.

Risk is accepted as part and parcel of our daily lives and Islamic history shows how risk was managed during the time of Prophets. Risk management is important from the Islamic perspective for the betterment of social well-being (Abdullah, 2012). This is evidenced by the following sources of Shari'ah.

"O Yusuf! O man of truth! Give us interpretation regarding seven fat cows which are being eaten by seven lean ones and seven green ears and the other seven dry; perchance, I may return to the people, perchance they learn He said. 'You will do cultivation for seven continuous years, then what you reap, leave it in its ear, but a little which you may eat. Then after it there shall come seven hard years, that shall eat up what you had stored up for them before, but a little which you may save. Then thereafter there shall come a year wherein people will have rain and in which they will press juice" (Surah Yusuf, 49 \&49)

"O my sons, Enter not all by one gate: enter ye by different gates. Not that I can profit you aught against God (with my advice): None can command except God: On Him do I put my trust: and let all that trust put their trust on Him" (Surah Yusuf, 67).

In the above Sūrah, Prophet Ya'qūb suggested to his sons not to enter through the same gate during the journey to Egypt in order to mitigate the risk. In addition, the following Qur'ānic verse shows that we are supposed to put effort for the betterment of our lives and then we should seek Allah's (SWT) help and guidance.

"Verily never will God change the condition of a people until they change it themselves (with their own souls)..." (Surah Ar-Ra'd, 11).

"...But on Allah put your trust if ye have faith." (Surah Al Ma"ida, 23)

Apart from the Qur'ānic verses, the following hadīths show the practice of risk management during the time of the Prophet (SAW).

"When the Holy Prophet (SAW) asked a Bedouin Arab, who entered the mosque with his camel left outside untied, if his camel would run astray, he said, "Inshaallah". The Prophet (SAW) then said: "Tie your camel first, then, say Inshaallah." (Sahih al Bukhari narrated by Anas bin Malik)

The above hadith is evidence that the Prophet (SAW) encourages us to strive to minimise the negative 
consequences and then pray to Allah (SWT) for His help and protection.

The Prophet's journey to Madinah is another evidence illustrating how he managed risk. In that journey, the Prophet asked Ali to sleep in his bed to reduce the risk of being murdered. One Islamic legal maxim (Qa'idah Fighiyyah) mentions the important role of "Al-Darar Yuzal" which means that damage or harm is removed. Thus, risk should be managed to mitigate the negative consequences of the peril and is encouraged in Islam.

\section{Insurance}

Insurance can be defined in many different ways. According to Siddiqui (1984),

"Insurance is based on the discovery of a useful social scientific principle, according to which after a small investment, individuals can be freed from incurring financial losses as a result of perils and accidents whose incidence can be measured fairly accurately in relation to large human groups".

"A financial arrangement whereby an individual substitutes a small cost (the premium) for a large uncertain financial loss (the contingency insured against)" (Vaughan \& Vaughan, 2001).

In other words, insurance is a contractual relationship between the insured and the insurer in which the insured pays the premium with the expectation of claiming the damages (if any) from the insurer. By doing so the risk of the insured is transferred to the insurer and it has been used as a risk management tool at the personal level and business level (Sharma, 2009). The main objective of insurance is to provide the financial damages to the insured and hence, as a rational decision maker, the insured are willing to pay the premium which is much smaller amount compared to the financial claims that they can make if any. From the side of the insurer, they have predicted the possibility of having claims from the groups of insured and they make sure that the premium that they receive is sufficient to cover the claims and related expenses as well as to make profit for themselves. Insurance is a precaution to minimise the financial loss that might be encountered in human life (Morgan, 1993). It is a convincing way of minimising the future financial risks and it is necessary when persons meet with situations that impose huge financial loss to the persons (Allen, 1936). Thus, insurance can also be used a planning tool for the unknown loss in the future which the insured might face (Muslehuddin, 1982).

If the historical development of insurance is reviewed, it can be traced back to ancient times. During the ancient period, forms of insurance were linked with trade such as shipping or over land caravans with an aim to supplant or replace goods lost, damaged, or stolen during long trading voyages. In those days, a system of indemnity known as a "Bottomry" contract was practiced in Babylon in the early period of the third millennium BC to reduce the risk of piracy on the high seas, plunder, and capture for ransom and risk of robbery. Later, Hammurabi's code became the first written laws. Bottomry contracts were also practiced by Hindus $600 \mathrm{BC}$ and Greeks in fourth century BC. In 215 BC, some historians traced the origin of insurance when the Roman Government required risk assessments from enemy attacks, storms, and further natural disasters for the construction of their ships (Kassar, 2008).

At the end of the seventeenth century, London's economy developed to become the centre for trade, which led to an increase in the demand for marine insurance. Mr. Edward Lloyd opened a coffee house in the late 1680s which became a breeding place of ship owners, merchants, and ship captains. Since then, the coffee point became a meeting place for parties wishing to insure or secure cargoes and ships and those willing to underwrite such ventures. At present, Lloyd's of London is leading the market for marine and other peculiar types of insurance. This form of insurance has become popular as it works rather differently from other forms of insurance (Sharma, 2009).

The marine insurance practiced today emerged in London's coffee house sixteen hundred (1600) years back. As shipping and trade began to increase between the new world and the old, new colonies were being set up and goods brought back. A coffee house owned by Edward Lloyd, became the meeting place for merchants, ship owners and other business concerns and this coffee house became known as Lloyd's of London. The fire insurance as we know today originated after the Great Fire of London which in 1666 engulfed and destroyed 13,200 houses. The consequences of this great mishap forced Nicholas Barbon to open an office to insure or give safety security to buildings in 1680. He setup England's first fire insurance company, "the fire office", to insure brick and frame houses (Sharma, 2009).

The prospect of insurance is tremendous. It shows that insurance is essential for us and provides financial assistance according to the insurance policy. However, the major problems with the current insurance practices is its involvement in interest, uncertainty, and gambling which are unethical and causes the insurance industry to be engaged in unethical business practices. 


\subsection{Insurance from the Islamic Perspective}

Due to the complex nature of our lifestyle and business exposure, we are directly or indirectly forced to have insurance. However, the practice of insurance involves prohibited elements. Insurance involves interest-based activity because insurance companies are not restricted in their investment in interest bearing businesses. In addition, the contractual relationship between the policyholders and the insurance companies is the contract of buying and selling resulting in the exchange of money for money. The premium as a monetary term is paid for the exchange of financial claims in the future. The collected premiums are then invested in interest-based activities.

Interest is prohibited in Islam because it creates an unfair and unjust society. If the borrower borrows money, he or she needs to pay the interest in addition to the principal borrowed regardless of the borrower's financial situation. The lender is guaranteed the payment of interest which is the additional amount above the borrowed money. The lender does not share the risk of incurring losses faced by the borrower. However, if the borrower profits from the invested money which is borrowed from the lender, the latter does not have a share of the profit other than the predetermined rate of interest. Thus, when the financial position of the borrower is bad, it is not fair to the borrower since the borrower needs to pay interest. When the borrower profits, the borrower does not share the profit with the lender and hence, it is not fair to the lender. Such an exchange cannot result in fairness to both parties. Thus, the involvement in interest results in an unfair and unjust society, rather than promoting brotherhood and social solidarity. The prohibition of interest is clearly mentioned in the following verse:

"O those who believe fear Allah and give up what still remains of the riba if you are believers. But if you do not, then listen to the declaration of war from Allah and His Messenger. And if you repent, yours is your principal. Neither you wrong, nor be wronged. And if there be one in misery, then deferment till ease. And that you leave it as alms is far better for you, if you really know. And be fearful of a day when you shall be returned to Allah, then everybody shall be paid, in full, what he has earned. And they shall not be wronged." (Surah Al-Baqarah, 275-281).

The existence of uncertainty in insurance practice renders conventional insurance noncompliant with Shari'ah. For instance, in the case of life insurance, the policyholder pays the premium to the insurance companies. However, the compensation the policyholders can get depends on the occurrence of some misfortune in the future. This means that without the specified misfortune, the policyholders will not receive anything and even if the peril occurs, how much will be received depends on the value of eligible damaged value and coverage in the insurance policy. Thus, from the side of policyholders, there are three possibilities, i.e. no compensation, the maximum compensation according to the contract if the eligible damaged value is equal or more than the predetermined maximum amount in the contract, or less than the predetermined maximum amount if the eligible damaged value is less than the predetermined maximum amount. From the perspective of insurance companies, how much they have to pay for the claims depends on the cost of the misfortune and hence they might need to pay the maximum predetermined amount or less than that amount. If there is no misfortune, the insurance companies do not need to pay anything. Similar to the insurance policyholders, there are three possibilities for insurance companies, i.e. no need to pay anything, need to pay less or the maximum predetermined payable claimed amount. From this scenario, policyholders are paying the premium but there is no accurate consideration in return. This highlights the uncertainty in the insurance contract and this practice, which renders it an invalid contract in Islam.

Uncertainty is prohibited in Islam since it will not result in fairness to the contracting parties and may cause dispute. The prohibition of uncertainty has been clearly mentioned in the Quran:

O you who believe! Intoxicants (all kinds of alcoholic drinks), and gambling, and Al-Ansab, and Al-Azlam (arrows for seeking luck or decision) are an abomination of Shaitan's (Satan) handiwork. So avoid (strictly all) that (abomination) in order that you may be successful. Shaitan (Satan) wants only to excite enmity and hatred between you with intoxicants (alcoholic drinks) and gambling, and hinder you from the remembrance of Allah and from As-Salat (the prayer). So, will you not then abstain? (Surah Al-Maeda, 90-91)

Conventional insurance is a form of gambling because if the policyholder does not make any claim, the insurance companies gain. On the contrary, if the policyholder makes the claim, it becomes an expense for the insurance companies. In any situation, it is favourable to one party while it is not fair to the other. Thus, it is prohibited in Islam. The prohibition of gambling has been clearly stated in the following verse:

They ask you [Prophet] about intoxicants and gambling: say, "There is great sin in both, and some benefit for people: the sin is greater than the benefit." They ask you what they should give: say, "Give what you can spare." (Surah alBaqarah, 219) 
The Islamic prohibition of insurance has led to the development of Takaful as an alternative. Some of the meetings which declare the prohibition of insurance are the First International Conference on Islamic Economics (Makkah) 1976, Resolution of the Fiqhi Academy of OIC 1985, Resolution 12/11 of Al Barakah Group Symposium, Resolution 42 of AlRajhi Bank-Saudi Arabia, Resolution of National Fatwa Committee of Malaysia 1972, Resolution of Dewan Syariah Nasional Indonesia 2001, and Resolution of Fiqh Council of Muslim World League 1978. The majority of Shari'ah scholars agree that the alternate form of insurance is allowed in Islam, provided that it must be based on the agreement of donation (uqud tabarruat), instead of the conventional commercial contract of exchange (uqud muawadhah), as the latter encompasses Riba, Maysir, and Gharar which nullify the conventional insurance agreement. (Salman, 2014).

\subsection{Insurance from the Perspective of Other Religions}

This section discusses the prohibition of insurance practices from the aspects of Hinduism, Buddhism, Christianity, and Judaism. Regarding interest, in Hinduism, Vasishtha, a prominent Hindu lawmaker, made a special law which forbade interest. Interest is considered defiling and selling one's wife or child (Manu Smriti: 11:62). In Buddhism, the oldest reference related to interest can be found in religious manuscripts of India, dating back to 2000-1400 BC. In the Buddhist Jatakas (600-400 BC), there are many references related to the prohibition of the payment of interest. In Christianity, St. Thomas Aquinas, the leading theologian of the Catholic Church opposes interest (Najmul, 2013). The following verse of the Bible prohibits the practice of interest:

"Take thou no usury of him, or increase: but fear thy God; that thy brother may live with thee. Thou shalt not give him thy money upon usury, nor lend him thy victuals for increase" (Leviticus 25:36-37).

In Judaism, the practice of interest is criticised in several passages of the Old Testament by stating that charging interest is scorned, discouraged, and prohibited and it is an exorbitant element for the borrower.

The element of uncertainty is prohibited in Hinduism, Buddhism, Christianity, and Judaism because it leads to social and economic injustice. Hinduism preaches that it is the responsibility of human beings to behave ethically by helping the society eliminate evil mind-sets. Hindu ethics are based on the saying, "if you injure your neighbour, you really injure yourself. If you injure any other creature, you really injure yourself, because the whole world is nothing but yourself" (Salman and Htay, 2014; Htay et al, 2013). When the society is involved in interest, it is not fair to the neighbours who are in need of money thereby causing social injustice. Buddhism arose in India as a spiritual force against social injustice. Ethics is required in business for economic justice and social harmony (Calkirs and Ngo, 2013). Christianity is based on the concept of loving thy neighbour. Jesus taught how human beings should love each other and demands giving favours to all who are in need. Jesus encourages an ethical and loving society. Judaism known as an "ethical monotheism" provides a moral law for all humanity. According to Judaism, the rich are responsible for the poor and in dealing with neighbours, the teachings of God say to love them as you love yourself. Giving to the needy is encouraged and the following scripture depicts how human beings should behave ethically in dealing with people:

"God has shown you, O Man, what is good; and what does the Lord require of you but to do justly, and to love mercy, and to walk humbly with your God?" (Micah 6:8)

Regarding gambling, Hindu scriptures prohibit gambling:

"A Gamester / gambler says, 'My wife holds me aloof, my mother hates me'. The wretched man finds none to comfort him" (Rigveda 10: 34:3).

Buddhism does not encourage gambling because it is the drain on one's store of wealth and debauchery. In Christianity, the Bible teaches that gambling is a sin. Under Judaism, the gambler could not be trusted as a witness in court. According to Rami bar Chama, profitable gambling is a simulation of theft (Salman \& Htay, 2014).

In summary, Islam, Hinduism, Buddhism, Christianity, and Judaism prohibit interest, uncertainty, and gambling. Since insurance has been prohibited, Takaful has been introduced as an alternative that is free from the prohibited elements.

\section{Takaful / Islamic Insurance}

Takaful is derived from the Arabic root word "kafala" which means guarantee or securing one's needs (Engku Rabiah and 
Hassan Scott, 2008). According to Dikko (2014), Salman \& Htay (2013) and Noordin (2014), Takaful is based on the concepts of Tabarru (i.e. voluntary donation) and Ta'a wun (i.e. mutual cooperation). It refers to a joint and mutual guarantee among the participant from a defined loss. The definition of Takaful provided by AAOIFI (2010, Page no. 385) is as follows:

"A system through which the participants donate part or all of their contributions which are used to pay claims for damages suffered by some of the participants. The company's role is restricted to managing the insurance operations and investing the insurance contribution."

Similarly, IFSB defines Takaful as:

"The Islamic counterpart of conventional insurance, and exists in both Family (and "Life") and General forms. Takaful is derived from an Arabic word that means joint guarantee, whereby a group of participants agree among themselves to support one another jointly for the losses arising from specified risks."

When the concept of Takaful is examined, it has the elements of mutual protection and shared responsibility. The practice of Takaful can be traced back to the ancient Arab tribes whereby the victim's relatives use to take the responsibility by making the mutual contribution in order to pay the bloody money as a financial help to the family of the deceased (Engku Rabiah and Hassan Scott, 2008; Hassan, 2011; Htay and Salman, 2013). This practice was approved by the Prophet (SAW) (Salman, 2014). The term "Takaful" is not written in the Qur'an. Nevertheless, its notion such as joint collaboration and assisting the needy is motivated in the Qur'an. The following verses highlight the necessity of Takaful and its legitimacy (Salman, 2014):

\footnotetext{
"...Help ye one another in righteousness and piety, But help ye not one another in sin and rancour..." (Surah Al Ma'ida, 2)

"...Allah intends every facility for you; he does not want to put to difficulties..." (Surah Al Baqarah, 185).

"... ye who believe! Eat not up your property among yourselves in vanities: But let there be amongst you Traffic and trade by mutual good-will." (Surah An-Nisa, 29).
}

Thus, the practice of Takaful is not new since it originated during the time of the Prophet as a mechanism to help the Takaful participants suffering some misfortune. Takaful as a Shari'ah approved product will help the needy in the society by promoting a sharing and caring atmosphere.

\subsection{Takaful and Maqasid Al Shari'ah (General Objectives of Shari'ah)}

Shari'ah is derived from the root Shin Ra 'ayn. Its literal meaning is the road to a watering place, and/or the straight path to be followed. Technically, it means all the different commandments of Allah to mankind. In other words, Shari'ah is the ruling that we are required to abide by in all aspects of our life, including business activities as revealed by Allah to the Prophet through the Quran and founded in sayings and acts of the Prophet, i.e. Sunnah (Ladin, 2011). Since Shari'ah is moulding our activities, this section discusses the extent to which Takaful can meet the objectives of Shari'ah and inject the concept of risk sharing in the society.

There are three general categories of Shari'ah objectives, namely the essentials (daruriyyat), the complementary (hajiyyat), and the embellishment (tahsiniyyat). The first objective, i.e. the essentials, aims to protect five values, i.e. the protection of religion ${ }^{1}(\mathrm{al}-\mathrm{din})$, the protection of life ${ }^{2}$ (al-nafs), the protection of dignity or lineage ${ }^{3}$ (al-ird), the protection of intellect ${ }^{4}(\mathrm{al}-\mathrm{aq})$, and the protection of property ${ }^{5}(\mathrm{al}-\mathrm{mal})$. The second objective, i.e. the complementary, is to provide the supplementary rules to achieve the five essential values discussed above. This second objective provides room to remove hardship and promote a comfortable life for human beings. For instance, travellers are allowed to break their fast

\footnotetext{
${ }_{1}$ Protection of religion is the first and foremost value that we need to preserve by understanding about Islam and its teachings.

2 Life is valuable to everyone and the life of the people should be protected without discriminating between the poor and the rich, Muslims and non-Muslims and leaders and subordinates.

${ }^{3}$ Protection of other people dignity is important to ensure that we do not harm others by accusing and to maintain the respect and privacy of others.

${ }_{4}^{4}$ Intellect is the gift of Allah and it should be protected and the views of other people should be considered in making the decision. In addition, any acts or action like drinking alcohol is prohibited since it will destroy the intellect of the people.

${ }^{5}$ Acquiring and protecting the property is essential and hence, the contract should be written properly in disposing and acquiring it to ensure that there will be no confusion and dispute.
} 
during the fasting month when undergoing difficulty during times of travel. The ill are also allowed to break their fasting. The third objective, i.e. the embellishment is to protect the desirable interest of others by promoting a more comfortable life for human being. Other general objectives of Shari'ah are related to providing education and upholding justice (al-adl) (Ladin, 2011).

According to Abdul Aziz (2010), the objectives of Shari'ah in acquisition and management of wealth are to circulate the wealth in the form of expenditure and investment by applying Shari'ah approved contracts, to promote transparency in managing the transactions, to ensure certainty (Thabat) in ownership before disposing the property, to be just and fair to all involved parties, and to strive to (l'wad) earn profit.

Takaful provides financial assistance to participants engaged under the Takaful contract. The basic operational model of Takaful is the funds are contributed by the participants and managed by the Takaful operators and then the eligible claims by the participants are paid out of the proceeds from the invested funds. In this way, the participants are mitigating their financial risk by contributing to the Takaful fund. Rather than suffering alone financially, their losses and needs are to some extent protected. The surplus, i.e. any balance of proceeds after paying the claims, is distributed and shared among the participants depending on the Takaful model adopted by the Takaful operators. Thus, when there is more surplus, the participants benefit. In contrast, when there are more claims and no surplus, the participants do not receive any surplus but must helping the financial needs of the unfortunate participants according to the contract. This shows that the participants are sharing the good and bad moments together consequently promoting a strong sense of brotherhood among the participants.

In summary, the Maqasid Al-Shari'ah seek to ensure that we treat others equitably and fairly and stimulate a caring and sharing society whilst meeting the needs of the society. Takaful meets the objectives of Shari'ah because it is a Shari'ah approved product and it has the elements of mutual protection and shared responsibility.

\subsection{Ethics and Takaful}

The term "ethics" comes from the Greek word "ethos" which means "character or custom" (Shaw and Barry). It has been defined in several ways:

"Ethics as an act where one holds the virtues including charity, justice and generosity to benefit himself and his society. Ethics has been recognized at various levels with different understandings and justifiable views" (Aristotle, 2007).

"Ethics is related to one's morality, humans acquire knowledge as rational beings in order to respect other rational beings. It is to put continuous efforts in studying one's own moral conducts and belief, with a solid base" (Immanuel Kant, 2015).

The theory of normative ethics under utilitarianism is defined, "as a course of action to maximize happiness and reduce suffering" (Singer, 2011). Business ethics is defined as the behavioural aspect of business that are guided by moral principles.

It is opined that ethics is for fairness and justice among human being and its importance is emphasized in Islamic finance as well (Marina Daras, 2013). The Arabic word "Akhlaq" (Ethics) which means "to create, to shape, to give form, to mould or to produce" (Ahmad, 2012). It provides a set of moral principles which judge what is right or wrong. Ethical values are important in all aspects of human life, including business activities. Historically evidence shows that Allah (s.w.t.) sent the Prophet as a role model to show good moral behaviours (Ibn Hambal, No: 8595). In Islam, ethical values are required in all aspect of daily life activities as seen in the following verses:

"And fulfil promise, for the promise shall be questioned about." (Surah Al-Isra, 34)

"Give full measure when ye measure, and weigh with a balance that is straight: that is the most fitting and the most advantageous in the final determination." (Surah Al-Isra, 35)

According to Ahmed (2015), ethical values refer to goodness (khayr), truth (haqq), righteousness (birr), equity (qist), equilibrium and justice (adl), and God consciousness (taqwa). We are required to observe and maintain the ethical values in portraying ourselves (ilm al-akhlaq), and dealing with family members (tadbir al-manzi) and society (siyasat-jmedina) (Emrullah \& Hadimi, 2014).

The foundation of Islam is Tawhid, i.e. Belief in Oneness of Allah and thus, He is the owner and creator of everything and $\mathrm{He}$ is the One who provides the complete set of moral values and principles. It is not allowed to make mischief on earth because it will displease Allah (s.w.t). It is obligatory for us to create a harmonious, peaceful, and just society and the objective of the corporation cannot be solely to make profit. They have to take care of the society. The Islamic financial system needs to be established based on ethics and social responsibility as part of their religious 
obligations. Due to that, Islamic finance needs to be free from interest, uncertainty, gambling, and other prohibited activities.

Islamic finance promotes universal brotherhood, high moral ethics, social equality and mutual welfare (Ethica's Handbook of Islamic Finance, 2013). Since Islamic finance is required to observe ethical norms and values which are founded on Shari'ah, it will be able to offer fair and transparent transaction, mutual assistance, and eliminate hardship (Ayub, 2007; Haniffa \& Hudaib, 2007). Since ethics is the corner stone of Islamic finance, international standard setting organisations such as the Islamic Financial Services Board (IFSB) and the Accounting and Auditing Organisation for IFls (AAOIFI) have published the Guiding Principles and Conduct of Business for Institutions offering Islamic Financial Services and the Code of Ethics for the Employees of Islamic financial institutions respectively.

According to IFSB (2009), "It promotes the development of a prudent and transparent Islamic financial services industry through introducing new, or adapting existing international standards consistent with shari'ah principles".

Takaful as part of the Islamic finance can be termed ethical insurance (Azmi, 2015; Mohd. Kasim, 2015). According to them, it is operating under the Islamic ethical framework and hence creates the atmosphere of a caring and sharing society while promoting solidarity. Takaful has been introduced as an alternative to insurance to ensure that people can participate in Takaful which is free from interest, uncertainty, and gambling. These elements are prohibited from the Islamic perspective due to unfair nature of their practices. They cannot provide a situation which is fair to both involved parties. It is always an advantage of one party at one situation. For instance, the borrower needs to pay interest regardless of its financial position and so the lenders have the upper hand to receive the interest and do not need to be worried. If the borrowers are in a good financial position from the investment due to the borrowed money, they do not need to share the profit with the lenders but to pay the required interest only. Hence, when the business is slow, it is not fair for the borrower, while when the business is booming, it is not fair to the lender.

In order to avoid unfairness, Takaful operators are allowed to use several types of Takaful models such as pure Mudarabah, modified Mudarabah, pure Wakalah, modified Wakalah, Hybrid model and Waqf model which will result winwin situation for both parties. For instance, in the Hybrid model, both Takaful participants and operator can share the profit and hence it creates social harmony and enhance brotherhood and mutual understanding. Takaful is free from uncertainty because Takaful is based on a unilateral contract whereby the participants contribute based on the concept of mutual contribution and the aim is to help other participants' financial needs and to receive financial assistance from other participants. In addition, it avoids gambling because the contractual relationship between them is based on the mutual help and assistance. This is contrary to conventional insurance, whereby when the Takaful operators need to pay the claims, they lose and when the insured do not make any claims, the operators win. Gain or loss in insurance depends on chance. With this, it is believed that Takaful is an ethical insurance.

\section{Conclusion}

Ethical behaviour is part of religious practices and thus it is the inherent responsibility of every one of us. It must be observed otherwise our lives will not be in harmony. All religions require us to help and cooperate each other and promote brotherhood and solidarity. Ethical society and environment cannot be achieved without eliminating interest, uncertainty, and gambling which are the main fostering elements of unethical practices, especially in the business environment. At the same time, we are directly or indirectly forced to have insurance whose practice is based on these elements. The rationale behind having insurance is to manage risk. We are exposed to risk and most of the times, it will result in financial loss for the misfortunate people. In order to mitigate the risk, most people subscribe to insurance. In some cases, the government requires certain types of general insurance products like motor insurance. Islam allows risk management but not involving in insurance due to its non-Shari'ah compliance nature and unethical flavour. Other religions also oppose interest, uncertainty, and gambling. Insurance practices are prohibited by religious teachings. Thus, Muslim scholars proposed the idea of introducing Takaful as an alternative to insurance to offer ethical insurance products which are free from interest, uncertainty, and gambling. This paper acknowledges the importance of ethics and risk management and thus suggests participating in Takaful to manage undesirable risks, to avoid religiously prohibited products, and to realise an ethical and just society.

\section{References}

Abdulaziz, A. B. (2010), "Al-Dhara'i'and Maqasid al-Shari'ah: A case study of Islamic insurance", Intellectual Discourse, Vol. 18(2), pp261.

Abdullah, S. (2012). Risk Management via Takaful from a Perspective of Maqasid of Shariah. Procedia-Social and Behavioral Sciences, 
65, 535-541.

Accounting and Auditing Organisation for Islamic Financial Institutions. (2010), "Accounting, Auditing and Governance Standards for Islamic Financial Institutions", AAOIFI, Bahrain, pp 385.

Ahmad, S. (2012), "The Concept of Islamic Work Ethic: An Analysis of Some Salient Points in the Prophetic Tradition", "International Journal of Business and Social science", Vol 3, (20), pp 116-123.

Ahmed, P. (2015), "Corporate Governance and Ethics of Islamic Finance Institutions", journal of Islamic Economics, Banking and Finance, Forthcoming. Available at SSRN: http://ssrn .com/ abstract=2356899.

Alhabshi, Syed Othman, Kamaruddin Sharif, Hamzah Abdul Razak \& Ezamshah Ismail, (2012), Takaful Realities \& Challenges, Pearson, Malaysia.

Allen, F.T. (1936). General principles of Insurance. New York.

Aristotle. (2007). The Nicomachean Ethics. Published by Filiquarian Publishing, LLC.

Ayub, M. (2007) Understanding Islamic Finance, West Sussex, John Wiley \& Sons Ltd.

Azmi, S. (2015), "An Islamic Approach to Business Ethics", available at: http://www. renaissance. com.pk/mayviewpoint2y5.htm, (accessed 10 September 2012).

Bailey, K., (1994), "Methods of Social Research, Fourth Edition", New York: The Free Press.

Calkirs and Ngo, (2013), "Synthesis of results for macroeconomic policy in a modern Buddhi state", Theravada macroeconomic.

Dikko, M. (2014). An Analysis of Issues in Takaful (Islamic Insurance). European Journal of Business and Management, 6(15), 1-5.

Emrullah, A. \& Hadimi, M. (2014), Ethics of Islam $10^{\text {th }}$ ed, Hakikat Kitabevi, Istanbul.

Engku, R., \& Hassan, S. (2008), Essential guide to Takaful (Islamic insurance), CERT publications, Malaysia.

Ethica's Handbook of Islamic Finance. (2013). Published by: Ethica Institute of Islamic Finance Dubai, United Arab Emirates. Retrieved on 2, January 2016. From http://www. ethicainstitute. com/Ethica_Handbook_of_Islamic_Finance .pdf.

Haniffa, Roszaini and Hudaib, Mohammad. (2007). Exploring ethical identity of Islamic banks via communication in Annual reports, Journal of Business ethics (76:97-116).

Hasan Rusni, (2011), Islamic Banking and Takaful 2nd Edition, Pearson, Malaysia.

Htay, S. N. N., \& Salman, S. A. (2013). Viability of Islamic Insurance (Takaful) in India: SWOT Analysis Approach, Review of European Studies, 5(4).

Htay, S. N. N., Salman, S. A., \& Meera, A. K. M. (2013), "Let's Move to" Universal Corporate Governance Theory", Middle-East Journal of Scientific Research, Vol. 15 (7), pp1047 1053.

Immanuel Kant. (2015). The Ethics of Immanuel Kant: Metaphysics of Morals - Philosophy of Law \& The Doctrine of Virtue + Perpetual Peace + The Critique of Practical Reason: Theory of Moral Reasoning.

Islamic Financial Services Board, (2009), "Guiding Principles on Governance for Takaful (Islamic Insurance) Undertakings". IFSB, Malaysia.

Kader, H. A., Adams, M., \& Hardwick, P. (2010), "The Cost Efficiency of Takaful Insurance Companies", The Geneva Papers on Risk and Insurance-Issues and Practice, Vol. 35 (1), pp. 161-181.

Kassar, Khlid. (2008). What's Takaful A guide to Islamic Insurance. Lebanon: Bisc Group, Beruit.

Ladin, M. A. (2011), Introduction to Shari'ah \& Islamic Jurisprudence, CERT Publication Sdn.Bhd, Kuala Lumpur.

Marina, Daras. (2013). Technology Aids Sharia Compliance for Islamic Finance's Rise. Retrieved on 2, January 2016. Fromhttp://cmmnews.blogspot.my/2013_11_01_archive.html.

Mohd. Kassim, Z. ${ }^{-}$A. (2015), "Takaful- "Defining Ethical Insurance", available at:http://www.actuaries.org/EVENTS/Congresses/Cape_Town/Papers/Life\%20Insuran

\%20\%28IAALS\%29/23_final\%20paper_Mohd\%20Kassim.pdf, (accessed 10 November 2013).

Morgan, T.w. (1993). Porter's laws of insurance. Landon: n.p.

Muslehuddin, Mohammmad. (1982). Insurance and Islamic Law. India: Adam Publications and distributors, New Delhi.

Najmul Hoda, (2013), "Interest: A Bane for the Society", available at: http:/l http://www.indianmba.com/Faculty_Column/FC987/fc987.html (accessed 12 November 2013).

Noordin, K., Muwazir, M. R., \& Madun, A. (2014). The Commercialization of Modern Islamic Insurance Providers: A Study of Takaful Business Frameworks in Malaysia. International Journal of Nusantara Islam, 2(1), 1-13. http://dx.doi.org/10.15575/ijni.v2i1.44

Payne, G. and Payne, J., (2004), "Key Concepts in Social Research", London: Sage Publications.

Salman, S. A, 2014. Critical review on the prevailing Takaful models. International Journal of Applied Business and Economic Research. Vol. 12, No. 4, pp. 1079-1088.

Salman, S. A. (2014). Contemporary Marketing Issues in Takaful. International Journal of Economic Perspectives, 8(4).

Salman, S. A., \& Htay, S. N. N. (2013). Future of Islamic insurance (takaful) in Indian market. Business Science International Research Journal, 1(1).

Salman, S. A., \& Htay, S. N. N. (2014), "Insurance in the Light of Religious Teaching and Ethics: A Case Study of India", Middle-East Journal of Scientific Research, Vol. 19(2), pp299 305

Sharma, deendayal. (2009). Banking and Insurance. India: Rajat publications New Delhi.

Siddiqui, Nejathullah Moahammed. (1984). Insurance in an Islamic Economy. UK: The Islamic foundation London.

Singer, P. (2011). Practical ethics. Cambridge university press.

Vaughan, J.E., and Vaughan, T., (2001). Fundamentals of risk and insurance (9th ed.).John wiley and sons. 